\title{
Pengembangan Soal Higher Order Thinking Skills (Hots) Bagi Guru Sekolah Dasar
}

\author{
Anggit Grahito Wicaksono ${ }^{1, a}$ dan Jumanto ${ }^{1, b}$ \\ ${ }^{1}$ Program Studi Pendidikan Guru Sekolah Dasar \\ Universitas Slamet Riyadi Surakarta, 57126, Indonesia \\ agarahito@gmail.com \\ bantokarof@gmail.com
}

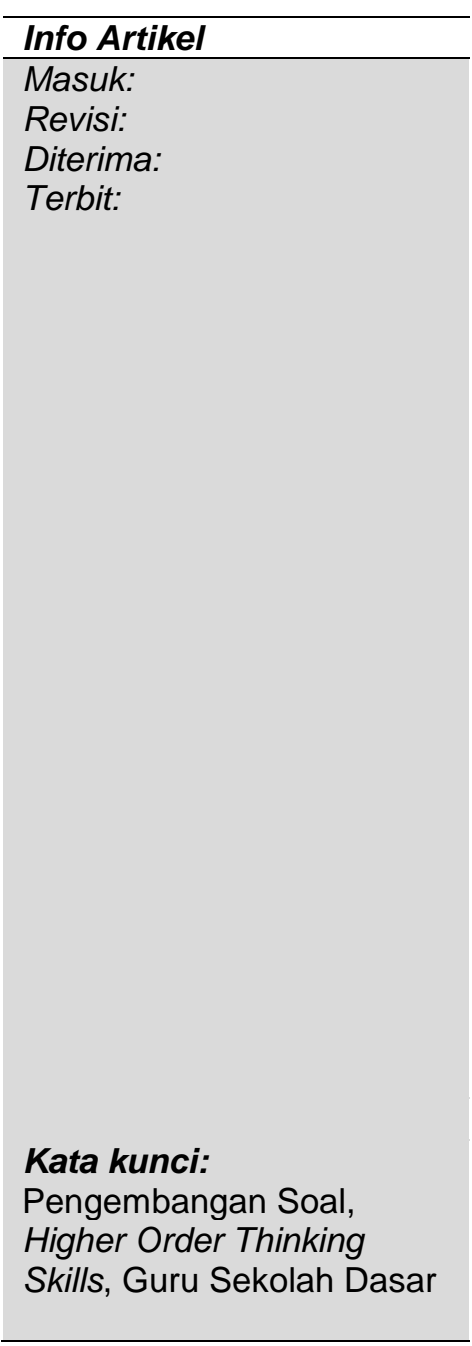

\begin{abstract}
Abstrak
Hasil survei TIMSS menunjukkan Indonesia berada di posisi bawah jika dibandingkan dengan beberapa negara di Asia. Upaya yang dapat ditempuh dalam mengatasi permasalahan tersebut adalah adanya pelatihan penyusunan soal HOTS bagi guru. Tujuan yang hendak dicapai dari program pengabdian ini adalah (1) memberikan pemahaman tentang ciri-ciri dan cara pengembangan soal HOTS yang berkualitas baik; (2) memberikan pengalaman langsung dalam mengubah soal biasa menjadi soal HOTS; dan (3) pengembangan soal HOTS bagi guru-guru di SD Djama'atul Ichwan Surakarta. Metode pelaksanaan pengabdian meliputi: (1) metode pendekatan yang dilakukan mulai tahap survei, perijinan, dan pemberian motivasi bagi guru yang akan mengikuti pelatihan (2) metode pelaksanaan program, meliputi tahap pendahuluan, tahap sosialisasi dan audiensi, tahap pelaksanaan, serta tahap evaluasi akhir. Target luaran yang dihasilkan melebihi target luaran yang diharapkan yaitu jumlah guru yang hadir dan mampu mengembangkan perangkat soal HOTS berjumlah 25 guru meningkat dari 21 guru yang ditargetkan. Hasil kuesioner tanggapan guru terhadap pengabdian yang telah dilakukan menunjukan bahwa materi pelatihan pengembangan soal HOTS sangat diminati dan dibutuhkan guru dalam pengembangan pembelajaran abad 21 dan menunjang era revolusi industri 4.0. Guru merasakan manfaat dari kegiatan pengabdian yang dilaksanakan karena dapat menjadi wawasan keilmuan baru dalam pengembangan kegiatan pembelajaran di sekolah. Luaran yang dihasilkan berupa perangkat soal HOTS sesuai dengan materi yang diampu guru serta implementasinya dalam pembelajaran di kelas, serta publikasi artikel pengabdian dalam jurnal ilmiah.
\end{abstract}

\section{PENDAHULUAN}

Pembelajaran itu merupakan suatu proses yang ditopang berbagai unsur. Salah satu unsur pendukung dari proses pembelajaran adalah guru. Guru sebagai tenaga profesional mempunyai fungsi, peran, dan kedudukan yang sangat penting dalam mencapai visi pendidikan 2025 yaitu menciptakan insan Indonesia cerdas dan kompetitif. Di dalam Permendiknas nomor 16 Tahun 2007 tentang kompetensi guru meliputi kompetensi Pedagogik, Kepribadian, Sosial, dan Profesional. Menurut Undang-Undang Nomor 14 Tahun 2005 tentang Guru dan Dosen, kompetensi pedagogik merupakan kemampuan yang berkaitan dengan pemahaman peserta didik dan pengelola pembelajaran yang mendidik dan dialogis. Secara substansi, salah satu kompetensi ini berupa 
kemampuan guru dalam mengevaluasi hasil belajar peserta didik. Hal ini sesuai dengan pendapat Marsh (1996) yang menyatakan bahwa salah satu kompetensi yang harus dimiliki guru adalah kemampuannya dalam melakukan penilaian, baik terhadap proses maupun produk pembelajaran.

Pada hakikatnya, penilaian adalah proses pengumpulan dan pengolahan informasi. Dalam pendidikan, penilaian berarti proses pengumpulan dan pengolahan informasi untuk menentukan pencapaian hasil belajar peserta didik. Untuk melaksanakan penilaian, guru memerlukan instrumen penilaian dalam bentuk soal-soal, baik untuk menguji aspek kognitif, afektif, maupun psikomotor. Instrumen penilaian yang digunakan guru untuk menguji hasil belajar peserta didik pada aspek kognitif biasanya diambil dari berbagai buku atau kumpulan soal-soal ujian. Soal dapat berupa uraian atau pilihan ganda. Kenyataan di lapangan, soal-soal cenderung lebih banyak menguji aspek ingatan. Banyak buku yang menyajikan materi dengan mengajak peserta didik belajar aktif, sajian konsep sangat sistematis, tetapi sering diakhiri soal evaluasi yang kurang melatih keterampilan berpikir tingkat tinggi (Higher Order Thinking Skills (HOTS)) peserta didik.

TIMSS adalah studi internasional yang mengukur kemampuan siswa di bidang Matematika dan Sains yang diinisiasi oleh the International Association for the Evaluation of Educational Achievement (IEA) (Kemdikbud, 2016). TIMSS merupakan studi yang diselenggarakan setiap empat tahun sekali, yaitu yang diawali tahun 1995 dan yang terbaru tahun 2015. Pada TIMSS 2015, target populasi siswa Indonesia adalah siswa kelas 4 untuk mengukur capaian Matematika dan Sains siswa SD/MI pada studi internasional (Litbang Kemdikbud, 2015). Indonesia berada di posisi bawah jika dibandingkan dengan beberapa negara di Asia. Hasil skor IPA menurut survei dari TIMSS yaitu pada tahun 2015 secara berurutan adalah 397. Perolehan skor sains tersebut menempatkan Indonesia pada peringkat 45 dari 48 negara. Hasil tersebut cukup memprihatinkan bagi sistem pendidikan di Indonesia.

Beberapa soal yang ditanyakan dalam TIMSS memang tidak terdapat dalam kurikulum Indonesia, menyebabkan guru harus berpikir keras tentang kecukupan materi yang diberikan kepada peserta didik. Selain itu, peserta didik belum terbiasa memecahkan soal yang berkaitan dengan aplikasi konsep dalam kehidupan dan soal yang memerlukan penalaran. Hampir sebagian besar soalsoal sains dalam TIMSS yang mengungkap aspek aplikasi (applying) dan penalaran (reasoning) tidak dapat dijawab oleh sebagian besar peserta didik Indonesia. Soal-soal tersebut hanya dapat dijawab jika peserta didik terbiasa diajarkan untuk menggunakan penalaran dan logikanya serta selalu dapat mengaitkan materi pelajaran dengan aplikasinya dalam kehidupan secara kontekstual.

Hasil TIMSS tersebut menjadi alasan logis bahwa guru saat ini diharapkan mampu mengembangkan soal Higher Order Thinking Skills (HOTS), yaitu soal-soal yang mampu mengungkap keterampilan berpikir (kognitif) tingkat tinggi. Namun, untuk mengembangkan soal HOTS masih banyak guru yang belum memahami dan menguasainya, baik ciri-ciri soal HOTS maupun cara mengubah soal biasa menjadi soal HOTS.

Guru Sekolah Dasar penting untuk dilatih mengembangkan soal yang termasuk soal HOTS. Penggunaan soal HOTS bertujuan untuk dapat menciptakan pembelajaran yang membuat peserta 
didik tertantang untuk mengembangkan keterampilan berpikir dan penalarannya. Berdasarkan hasil wawancara dengan kepala sekolah SD Djama'atul Program Utama Surakarta diperoleh informasi bahwa sebagian besar guru belum memahami dan menguasai dalam penyusunan soal HOTS. Guru masih awam dengan ciri-ciri soal yang terintegrasi HOTS serta cara mengubah dan mengembangkan soal biasa menjadi soal HOTS. Padahal perkembangan pola pikir peserta didik semakin maju yang seharusnya diikuti dengan kemampuan guru dalam membuat soal yang dapat mengungkap aspek kognitif tingkat tinggi, seperti soal aplikasi (applying) dan soal penalaran (reasoning) Bentuk soal yang mampu mengungkap kognitif tingkat tersebut dikenal dengan istilah soal HOTS yang seharusnya dikuasai oleh guru, agar peserta didik terbiasa dengan soal yang menantang keterampilan berpikir dan penalarannya. Namun, pada kenyataannya masih banyak guru yang belum memahami dan menguasai cara penyusunan dan pengembangan soal HOTS seperti yang diamanahkan dalam Kurikulum 2013.

Kegiatan Pengabdian kepada Masyarakat ini bertujuan untuk memberikan pemahaman tentang ciri-ciri dan cara pengembangan soal HOTS yang berkualitas baik, memberikan pengalaman langsung dalam mengubah soal biasa menjadi soal HOTS, serta pengembangan soal HOTS bagi guru-guru di SD Djama'atul Ichwan Surakarta. Melalui kegiatan ini diharapkan mampu menumbuhkan kesadaran guru-guru di SD Djama'atul Ichwan Surakarta tentang pentingnya mengembangkan kemampuan mengevaluasi peserta didik dengan selalu mengikuti perkembangan yang terjadi di dunia pendidikan, sehingga dapat meningkatkan kompetensi paedagogiknya. Akhirnya, diharapkan peserta pelatihan ini dapat menularkan pengetahuan yang diperoleh kepada guru lain yang belum mendapat kesempatan mengikuti kegiatan ini, baik di lingkungan sekolahnya masing-masing maupun sekolah lain. Tujuan dari program pengabdian adalah (1) memberikan pemahaman tentang ciri-ciri dan cara pengembangan soal HOTS yang berkualitas baik; (2) memberikan pengalaman langsung dalam mengubah soal biasa menjadi soal HOTS; dan (3) pengembangan soal HOTS bagi guru-guru di SD Djama'atul Ichwan Surakarta.

\section{BAHAN DAN METODE}

Metode pelaksanaan yang dilakukan mulai (1) tahap survei, perijinan, dan pemberian motivasi bagi guru yang akan mengikuti pelatihan (2) metode pelaksanaan program, meliputi tahap pendahuluan, tahap sosialisasi dan audiensi, tahap pelaksanaan, serta tahap evaluasi akhir.

Tahap pendahuluan dilaksanakan dengan mempersiapkan surat ijin dengan pihak terkait, mempersiapkan tempat pelatihan, mempersiapkan materi, alat, dan bahan. Tahap sosialisasi dan audiensi dilakukan dengan cara memberikan pelatihan pengembangan soal Higher Order Thinking Skills (HOTS) dilakukan dengan cara mengumpulkan guru-guru SD Djama'atul Ichwan Surakarta dan diberikan penjelasan mengenai perangkat soal HOTS serta cara pengembangannya.

Tahap pelaksanaan kegiatan pelatihan dilakukan dengan memulai pelatihan pengembangan soal HOTS dan sosialisasi program dilakukan dengan metode ceramah partisipatif, interaktif, dan dialogis. Sehingga peserta pelatihan dapat dengan mudah memahami dan menerapkannya dalam 
pengembangan soal HOTS sesuai dengan materi mereka masing-masing. Proses pelaksanaan pengabdian dilakukan dengan metode ceramah, tanya jawab, diskusi, dan praktek secara langsung.

Tahap evaluasi kegiatan dilakukan dengan cara mengevaluasi kegiatan pelatihan penyusunan perangkat soal HOTS agar dianalisis kelebihan dan kekurangan selama pelaksanaan pengabdian kepada masyarakat menggunakan kuesioner tanggapan guru terhadap kegiatan pengabdian kepada masyarakat.

\section{HASIL DAN DISKUSI}

Hasil yang dicapai dari kegiatan pengabdian kepada masyarakat ini adalah meningkatnya kemampuan dan keterampilan guru SD Djama'atul Ichwan Surakarta dalam penyusunan perangkat soal HOTS (Higher Order Thinking Skills). Hal ini berdasarkan evaluasi dan simulasi pada pelatihan dari kegiatan pengabdian kepada masyarakat dapat diketahui bahwa yang semula peserta belum memahami dan terampil dalam menyusun perangkat perangkat soal HOTS, maka setelah kegiatan kemampuan dan ketrampilan guru meningkat. Guru dapat mengerti dan memahami kriteria-kriteria dalam penyusunan perangkat soal HOTS dan kemampuan penyusunan perangkat soal HOTS juga menjadi lebih baik dan berkualitas. Target yang direncanakan bahwa dari jumlah peserta yang mengikuti pelatihan yaitu 30 orang diharapkan $75 \%$ peserta yang hadir yaitu 21 orang, tetapi pada pelaksanaannya yang hadir 25 orang. Hal tersebut menunjukkan bahwa guru-guru antusias untuk mengikuti kegiatan pengabdian masyarakat. Hal ini dirasa cukup berhasil mengingat bahwa guru yang hadir melebihi target.

Hasil kuesioner tanggapan guru terhadap pelaksanaan pengabdian dapat dilihat pada Tabel 3.

Tabel 3. Tanggapan Guru terhadap Pelaksanaan Pengabdian

\begin{tabular}{|c|c|c|c|c|c|}
\hline \multirow[t]{2}{*}{ No } & \multirow[t]{2}{*}{ Pernyataan } & \multicolumn{4}{|c|}{ Persentase (\%) } \\
\hline & & SS & $\mathrm{S}$ & KS & TS \\
\hline 1. & $\begin{array}{l}\text { Saya merasa sangat tertarik } \\
\text { dan ingin tahu tentang } \\
\text { materi pengabdian yang } \\
\text { akan diberikan. }\end{array}$ & 14,29 & 85,71 & 0,00 & 0,00 \\
\hline 2. & $\begin{array}{l}\text { Saya merasa kegiatan } \\
\text { pengabdian semacam ini } \\
\text { tidak memberikan manfaat } \\
\text { bagi pengembangan } \\
\text { pembelajaran di sekolah. }\end{array}$ & 0,00 & 0,00 & 71,43 & 28,57 \\
\hline
\end{tabular}


3. Saya merasa senang karena 38,10

61,90

0,00 0,00 materi yang diberikan sangat saya butuhkan dalam pembelajaran.

\begin{tabular}{|c|c|c|c|c|c|}
\hline 4. & $\begin{array}{l}\text { Saya merasa materi yang } \\
\text { diberikan terlalu sulit dan } \\
\text { tidak bisa saya pahami. }\end{array}$ & 0,00 & 0,00 & 90,48 & 9,52 \\
\hline 5. & $\begin{array}{l}\text { Kegiatan pengabdian telah } \\
\text { dilakukan dengan metode } \\
\text { yang tepat sehingga saya } \\
\text { dapat mengerti materi yang } \\
\text { disampaikan. }\end{array}$ & 9,52 & 80,95 & 9,52 & 0,00 \\
\hline 6. & $\begin{array}{l}\text { Saya merasa terpaksa ikut } \\
\text { pengabdian ini sebab saya } \\
\text { sangat awam dengan materi } \\
\text { yang diberikan. }\end{array}$ & 0,00 & 0,00 & 80,95 & 19,05 \\
\hline 7. & $\begin{array}{lcr}\text { Saya } & \text { merasakan } & \text { manfaat } \\
\text { yang signifikan } & \text { setelah } \\
\text { mengikuti } & \text { kegiatan } \\
\text { pengabdian ini. } & \end{array}$ & 9,52 & 76,19 & 14,29 & 0,00 \\
\hline 8. & $\begin{array}{l}\text { Setelah mengikuti } \\
\text { pengabdian ini, saya merasa } \\
\text { mendapatkan semangat dan } \\
\text { inspirasi baru. }\end{array}$ & 23,81 & 76,19 & 0,00 & 0,00 \\
\hline 9. & $\begin{array}{l}\text { Saya akan } r \text { mulai } \\
\text { mengaplikasikan materi } \\
\text { pengabdian ini untuk } \\
\text { menunjang pembelajaran di } \\
\text { sekolah. }\end{array}$ & 14,29 & 85,71 & 0,00 & 0,00 \\
\hline 10. & $\begin{array}{l}\text { Saya berharap kembali } \\
\text { dilibatkan kegiatan yang } \\
\text { sejenis di waktu yang akan } \\
\text { datang. }\end{array}$ & 14,29 & 85,71 & 0,00 & 0,00 \\
\hline
\end{tabular}

Tabel 3 menunjukkan bahwa butir pernyataan positif yaitu pada nomor 1,3,5,7,8,9, dan 10 sedangakn butir negatif pada pernyataan 2,4 , dan 6 . Butir pernyataan positif dengan persentase jawaban sangat setuju tertinggi adalah pada butir nomor 3 dengan perolehan 38,10\%. Hal tersebut menunjukkkan bahwa guru merasa senang karena materi yang diberikan sangat dibutuhkan dalam pembelajaran. Sedangkan butir negatif dengan persentase tertinggi adalah butir nomor 2 dengan persentase $28,57 \%$ menjawab tidak setuju. Hal tersebut menunjukkan bahwa guru-guru merasa bahwa dengan adanya kegiatan pengabdian memberikan manfaat bagi pengembangan kegiatan pembelajaran di sekolah. Hasil analisis tanggapan guru terhadap pelaksanaan pengabdian kepada masyarakat menunjukkan bahwa materi pelatihan pengembangan soal HOTS sangat diminati dan dibutuhkan guru dalam pengembangan pembelajaran abad 21 dan menunjang era revolusi industri 4.0. Guru merasakan manfaat dari kegiatan pengabdian kepada masyarakat yang dilaksanakan 
karena dapat menjadi wawasan keilmuan baru dalam pengembangan kegiatan pembelajaran di sekolah.

Sebagian besar guru SD Djama'atul Ichwan Surakarta telah berubah pandangannya tentang penyusunan pengembangan soal HOTS serta soal tes menjadi lebih mengarah atau berorientasi pada keterampilan berpikir tingkat tinggi. Hal ini dirasa cukup berhasil mengingat SD Djama'atul Ichwan Surakarta merupakan sekolah dasar yang selalu ingin maju dan meningkatkan kualitas guru.

Diharapkan setelah kegiatan ini pada tahun ajaran berikutnya akan ada program kerja yang berisi kegiatan pelatihan yang terkait dengan teknik yang baik, mudah, dan efektif sesuai dengan kriteria kurikulum 2013 sebagai pelatihan lanjutan yang cukup diminati oleh guru SD. Selain itu juga dapat dilakukan pelatihan penggunaan aplikasi penilaian berbasis kurikulum 2013 yang saat ini menjadi masalah yang terjadi dalam implementasi kurikulum 2013 di sekolah dasar. Hal ini berdasarkan masukan dari beberapa guru yang mengeluhkan tentang implementasi kurikulum 2013 dan penilaian pembelajaran pada kurikulum 2013 yang masih belum dipahami dan dikuasai oleh guruguru di SD Djama'atul Ichwan Surakarta.

\section{KESIMPULAN}

Berdasarkan uraian sebelumnya maka dapat disampaikan bahwa kegiatan pengabdian masyarakat bagi guru SD Djama'atul Ichwan Surakarta menghasilkan kesimpulan sebagai berikut:

a. Pelatihan pengembangan soal Higher Order Thinking Skills (HOTS) yang dilaksanakan dapat menigkatkan kemampuan dan keterampilan guru dalam menyusun perangkat soal tes dengan lebih berkualitas baik.

b. Upaya peningkatan persepsi guru SD Djama'atul Ichwan Surakarta tentang pengembangan soal HOTS telah disampaikan dalam ceramah dan pelatihan selama satu hari dilanjutkan pendampingan selama dua hari.

c. Menemukan masalah mendasar terhadap belum optimalnya implementasi kurikulum 2013 di sekolah yaitu guru masih merasa kesulitan dalam memahami implementasi kurikulum 2013 dan penyusunan penilaian pembelajaran yang sesuai dengan kurikulum 2013 khususnya dalam penerapan sistem penilaiannya menggunakan aplikasi penilaian.

\section{UCAPAN TERIMA KASIH}

Ungkapan terima kasih saya berikan kepada Rektor dan Kepala Lembaga Penelitian dan Pengabdian kepada Masyarakat yang telah memberikan kesempatan dan pendanaan untuk melaksanakan kegiatan pengabdian kepada masyarakat ini dengan lancar dan sukses. Terima kasih 
juga saya ungkapkan kepada SD Djama'atul Ichwan Surakarta yang telah memberikan kesempatan untuk berbagi ilmu dan diskusi terkait dengan pengembangan soal HOTS dengan guru-gurunya.

\section{REFERENCES}

Depdiknas. (2005). Undang-Undang Nomor 14 Tahun 2005 Tentang Guru dan Dosen. Jakarta: Depdiknas.

Depdiknas. (2007). Permendiknas No.16 Tahun 2007 tentang Standar. Kualifikasi Akademik dan Kompetensi Guru. Jakarta: Seketariat Negara.

Kemendikbud. (2016). Seminar Hasil TIMSS 2015 oleh Rahmawati. Jakarta: Puspendik Kemdikbud.

Litbang Kemendikbud. (2015). Survei Internasional TIMSS. Jakarta: Penelitian dan Pengembangan Kemendikbud.

Marsh, Colin. (1996). Handbook for Beginning Teachers. Sydney: Addison Wesley Longman Australia Pry Limited. 